ABORIGINAL HISTORY $19793: 2$

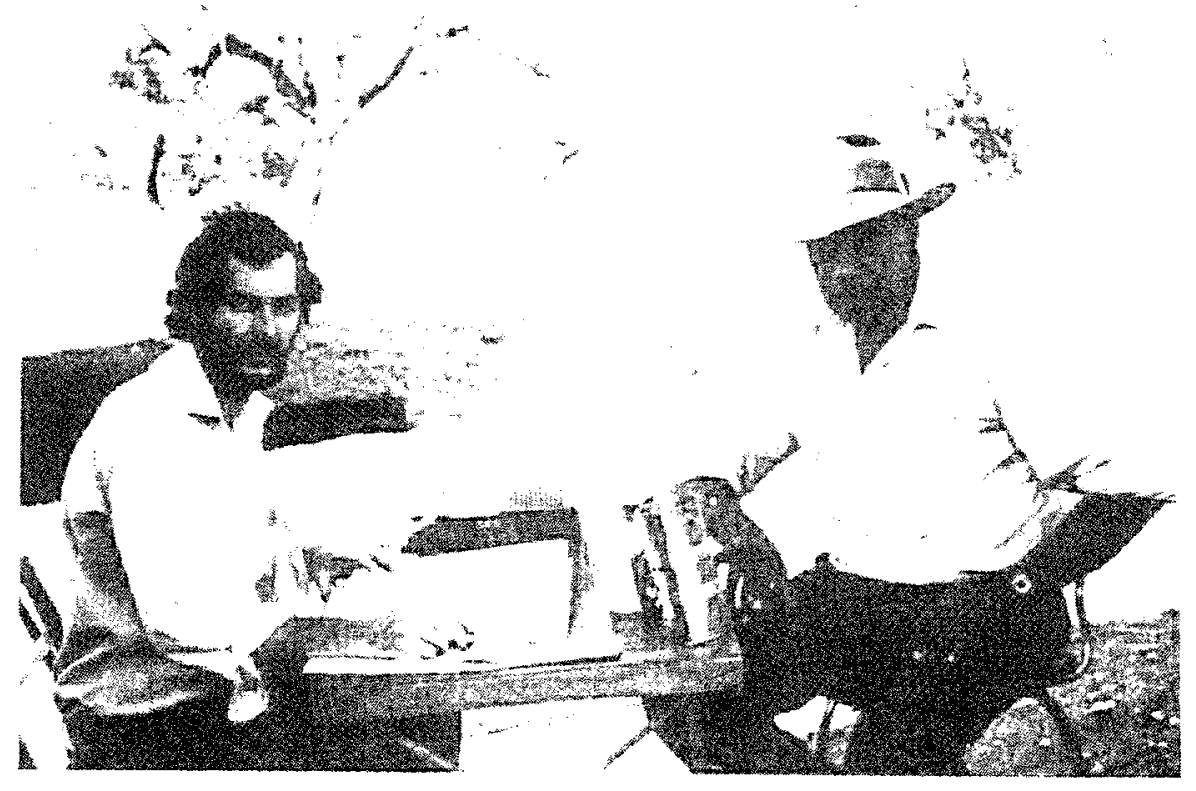

Bruce Shaw and Jack Sullivan, Turkey Creek, October 197 i

Photograph courtes? of Bruce Shaw 


\title{
'THEY SAME AS YOU AND ME': ENCOUNTERS WITH THE GADIA IN THE EAST KIMBERLEY
}

\author{
Bruce Shaw and Jack Sullivan*
}

Jack Sullivan was born on Argyle station in 1901 to a European father of the same name and a 'fullblood' Aboriginal woman of Djamindjung background. He grew up on the station and in his twenties 'came over to the white side', a choice which was explicitly presented by European station managers to many 'half caste' Aborigines when they came of age to enter fully into the stock work economy. The choice made was irreversible. Thereafter Jack never fully participated in the traditional 'Law' of the Aboriginal community to which he was related. A few years after the death of Patsy Durack in 1933, Jack 'pulled out' of Argyle station and followed the life style of the 'bag man', working on the Dunham River, Mabel Downs and Lissadell stations. In 1971, he retired from station life because of ill-health and set up camp with his fullblood half-brother Bulla Bilingiin on the Kununurra Aboriginal camping reserve (Mirima Village). I met him two years later and together we began recording his life history. Jack is one of the few remaining 'old identities' of the East Kimberley. Some anecdotes from his younger days are recorded by Mary Durack. ${ }^{1}$ The reminiscences given here refer to the period between 1880 and his early childhood. Jack now lives in comfortable retirement at Turkey Creek.

Editing, transforming the narratives from the spoken to the written word, was relatively extensive. Together we have had more than forty recording sessions, continuing our discussions and revisions while proof reading. I strove to remain faithful to the original spirit and idiom of the accounts, at the same time placing them into standard colloquial English. The reader may detect that parts of the narrative are responses to questions. This was unavoidable, for it is the way in which such material must be gathered, intensively, with care and cross-referencing where possible. Unnecessary questioning and comment was on the whole kept to a minimum, though not always successfully. The following extract from one of the conversations between Jack and $I$ in 1973 serves to illustrate how the original transcript appeared.

Old native bushrangers like?

I THINK SO, YEAH.

Old Major. Was up ere Texas. Not that feller? We didn't talk about that?

NO WE DIDN'T WE...

No but we said about something that one now.

WE WERE GOING TO YEAH.

You know this story, Bulla, if I go wrong, you put me on the track? But what I heard from Sammy's father see.

MMMM.

You got it on now? [The tape recorder]

YEAH YEAH.

Yeah, ow to start at Major, Kelly broughtim from Darwin. Jack Kelly. Brought Major from Darwin. He reared Major up. And Major got a y'know, bigger an bigger an bigger. An Kelly was a hard man on the boy. Used to belted Major, an y'know hangim up by the tree an all that stunt. Or put it over, throwim in the waterhole or sometime early in the morning or, sometime over night e'll put im in a big sack bag an hangim up a tree.

MMMM.

* These reminiscences are a slightly abridged version of a chapter in a book-length life history which we have tentatively titled Banggaiyerri: the story of Jack Sullivan.

1 Durack 1935, 1940. 
All that stunt y'know, e was a cruel feller this Kelly.

YEAH.

An Major got it y'know, bigger an bigger an stronger an, reckon e got fed up with old Kelly, so he got stuck into old Kelly. He belted old Kelly. See everytime any row Major just go up an slap old Kelly over. Y'know. He was y'know bluffin old Kelly. In them days they don't, didn't like to be any bluffed, like. From the black-feller or anybody. Them old white feller like, they was pretty hard blokes.

\section{WHAT D'YOU MEAN BY BLUFF? STANDING UP TO HIM?}

Yeah.

Documenting the lives of such men as Grant Ngabidj, Sandy McDonald and Jack Sullivan is one way in which I reached a greater appreciation of Aboriginal history from the people's perspective. The recording and interpretation of these reminiscences is one of the newer roles being filled by social scientists in this country. It is a form of anti-intellectualism to take the view that recent history, for the span of a little more than an elder's life time, is irrelevant for the present day. Many Europeans appear to hold this assumption, if current affairs discussions in the media are any guide, but recent history cannot be brushed aside. To believe that the historical legacy can have little effect today is the negation of common sense.

I believe one of the results of this movement is that the dichotomy between recent history and 'now' is becoming less sharp. There appears to be a kind of 'new wave', a critique in this country centring upon Aboriginal history from the Aboriginal perspective. Barwick, Unry and Bennett have brought together much of this material for the first time. However, publications on Aboriginal history by Aborigines, with or without European editors, are yet relatively few in number. Twenty-two Aboriginal authors are listed in the section on 'Aboriginal biographies and reminiscences' and fifty-six in the section titled 'Recording social change'. ${ }^{2}$ If the editorial contributions of European academics and commentators were removed the list would be considerably shorter. This is clearly strong evidence for a continued need to record Aboriginal history, and it seems to me that there is an important role for the partisan social scientist: the recording and interpretation of reminiscences from Aborigines who are unable through unfamiliarity with English, or illiteracy, incapacity such as age or injury, or because of busy work schedules, to do it alone. Accounts like Jack Sullivan's provide both new information and a new perspective for the writers of Australian history, who rely mainly on European records. Such studies are by no means antiquarian. They can throw light on the complexities of social change in rural areas like the East Kimberley.

Given the circumstances of Jack's life, it would be relatively easy to draw a picture of him as a person of mixed European-Aboriginal descent caught between two cultures. This word 'between' has appeared of ten enough in books on race relations in Australia to be a cliche. ${ }^{3}$ For that reason alone I think some of the assumptions implied in its use should be challenged. Stereotypes are to be distrusted in spite of the 'truths' upon which they are often based. Was Jack 'caught' between the worlds of the 'blackfeller' and the white man? Firstly, Jack's choice was made in response to the attitudes and expectations of all three status categories in the paternal, caste-like milieu in which he lived: fullblood Aborigines, half castes, and white men. Jack belonged to the two overlapping subcultures of fullbloods and half castes, which in turn were subsumed in the subculture of cattle station stockworkers. Because Europeans called the tune politically, half castes tended to identify more nearly with

2 Barwick, Urry and Bennett 1977:126-128; 141.169.

3 For example, Batty 1963; Hilliard 1968; Palmer and McKenna 1978. 
them. Secondly, by his own account Jack led a relatively happy life. Like many of his contemporaries he was a multicultural person. Job satisfactions and human relationships on the whole afforded him immense pleasure and interest, and do so to this day, although they were not without their conflicts. Clearly he did not participate in the activities of his Aboriginal relatives as fully as he might have done; nor did he have many dealings with fullblood Aborigines outside his kinship circle. But these were accepted facts of life. I put the question to Jack recently and this was his response: Y'know we used to go away workin in the yard somewhere. They used to say, "Why don't you come up to us? You're workin like a white feller". I went to the boss after that. Then I pulled out like. I was just glad to get away from the mob. [But you still had something to do with Bulla?...] Oh yeah. Must have friend y'know. Family y'know, never leave them right out. When they want anything they come up to my camp an sit down an I just givim what they want. But I never mix up with all the others.

\section{Reminiscences by Jack Sullivan}

I was with my mother in the bush every holiday until I was brought up and over twenty, then they put me among the white people. We left the blackfellers and were with the white men all the time. We did not go down to the boys' camp; we could not go and talk with them. If you wanted to have a bit of a talk you had to sneak around. A lot of fellers would do that to have a corroboree and the boss or head stockman would not know. They would not let you go and have a bloody talk; the manager and all were shamed. They classed us as white men and we could not go back with the blackfellers. We had to sneak round to get a bit of girl, the same as the white man, instead of camping with them. You might go over and tell the girl to go down and meet you, for you could not go into their camp. You were sacked from the station if you did that, and if you went anywhere else every white man would be up against you: "You no good, you no good; you real blackfeller then". They used to call us blackfellers straight away if we did anything like that: "Oh you a dog: you a blackfeller. You want to go down an joinim". Yes, once they took you off the blackfellers and put you with the whites you could not go back again.

In those days white men and we half castes treated the blackfeller like a dog. We could go in and belt him or take his stud away for a night. That was why some fellers were speared, some half castes too, through chasing the black girls. The blackfellers would say: "Oh you a white man bugger; you biin leavim us", and they always had something up against us, all the yellow fellers. They would tell you their opinion today a lot of fellers. Now I do not go and join them playing cards. I cannot. I was brought up as a white and cannot face the blackfeller. I cannot sit down and have a yam with them. It is all right with my brothers Friday and Bulla but I cannot go out on the corroboree camp and sit down among the blackfellers and have a yarn and play cards. I could go and play with the girls all right - that was the white man's bloody idea - but I do not join the girls much here, only old Peggy and all those, with whom I might have a joke and a bit of a talk. Peggy was nice, especially when she was young.

I was experienced on the job as a stockman and everything. Breaking in horses or mules was a white man's job. By and by when yellow fellers got experience they could do it too. They paid me. In those days there was not big wages. I started off with thirty bob a week Later we got only two pound eight shillings a week as white men for wages. The head stockman got five pounds and the cook I think four pounds. Being a head stockman meant that you had a hold of the game and had a station team young enough to do work. The blackfellers did not get any thing as yet, only the white man and the yellow fellers. The boys were only just getting bread and meat in those days; they were under the white men. 
There was some reason to iate the blackfellers in my days. I had to work them same as the white men; I had to liven them up. When they did not do what you told them, bang you went, knocked them over and all that. I was a bad bugger when I was in my time like: "Get out an get your bloody horse up. If you sleep over there well I jump the bloody horse on topa you", and that kind of thing. Old Johnny Walker did the same but he was never rough, just growling. I did a little fighting in my time; say, going and getting the calf horses early. Old Bulla was not a savage man with all the blokes who were with him but he used to work them hard.

It was pretty good in my days, peaceful, but in the earlier days when they came in to get Australia the white feller had to fight his way. When they did get a bit of ground to stand on they had to fight the blackfellers to get that land. And then they took the blackfellers afterwards and made them kings or something, to lift up their head and all that. They got a bit of ground, quietened the blackfellers, tamed them down and worked them. When the blackfellers had been made to understand the white man's way they were helping the white man then and fighting these wild ones. They would go up and talk to the wild ones in their lingo: "You wanta come up an me feller workin now. You can't killim bout bullock anything well they shoot you". But a lot of blackfellers would not come in; they wanted to fight them. Well, then they put a bullet in them. But the good blackfellers that came in, well they were all right. If the white man saw that that blackfeller was all right he put him in. If he ran away he would follow him and bring him back. If he ran away again well he followed him and shot him. That was what it was all about in those days. You see, they tamed one another, agreeing with one another. ${ }^{4}$ It was mostly before my time, but I saw a lot of it also when I was only a little boy, a few like that, not many. I know that in my time there were a few at Lissadell and one or two at Argyle. I saw them tied up at the post and then taken away the next morning and done in, the bush blacks. They would get a bush black and bring him in.

I think they came out in 1880 or something, Durack and Kilfoyle together from New South Wales. ${ }^{5}$ They formed the stations, on Stockade Creek first, and then they shifted over to the Behn only eight miles across when they reckoned Stockade was not good enough or something. Straight across at eight miles old Argyle was, on the Stockade Creek. Argyle and Rosewood were on the same creek when they first started. I suppose they picked out a better spot on the Behn for their cattle and their watering place and all that stunt. I have no idea why it was called Stockade. They were all named in the older days by Durack and Kilfoyle when they first came out. And they were there ever since till they sold out and the homestead went under the water. Things were peaceful only in the middle here. I think there was more murdering way down under and back on both sides. There was a lot of shooting down here in the west at the back of Wyndham way over Kalumburu way and all through there. A few got shot there and a white man was killed and all that, speared. At Mabel Downs

4 See McGrath 1978 for a discussion of the idea of 'taming' in early contacts along the north west Australian frontiers.

${ }^{5}$ The Ord River Station was the first East Kimberley homestead to be founded and stocked in 1884 . In 1885 the Duracks settled Lissadell. Argyle Downs and Rosewood stations were established in 1886. Wave Hill Station in the Northern Territory (abutting the East Kimberley region) was selected in 1880, and the Victoria River area stocked in 1883 (Durack 1933; Meggitt 1962:19). 
Creek they killed six thousand 6 blacks I think, all burned beside the hill there. The mound is still there where they buried them on the side of the ridge. Actually there were three creeks running together. The government now calls it Mabel Creek but it was named Cartridge Creek. Where they cleaned out all the blacks in the early days they reckon there were about six thousand cartridge shells right where they got them, right outside the iron gate there where the crossing is. Old man Bridge told me that, on the map and everything. When Mabel Bridge, one of Joe Bridge's daughters, was born there they named the spring after her and so it changed from Cartridge Creek to Mabel Spring. Everybody, the Bridges, Muckelton and McKenzie all had little blocks there in the early days.

\section{Johnny Durack}

When I was a snipe I heard how Johnny Durack got bloody speared here between Argyle and Rosewood and killed, and they went out and fought the blackfellers. ${ }^{7}$ In those days you had to have a bloody squirt in your belt all the time because bad blackfellers could meet you anywhere and drive a spear into you; so a white man when he met a blackfeller would pull the gun out and shoot him. One had to win out on one side, the white or black. They all had the wind up on each other, right up to my bloody time. When they started forming the stations, Johnny Durack would ride around from the old station four miles out from Argyle. He had a pack and rode round and round to find the good places for stations. He was in the lead and another feller was driving his pack. He put down to where he was going to cross a creek and that was where he ran into the blackfellers. Instead of frightening them away he straightaway pulled out a gun - bang bang bang bang - and chased one feller down to the creek. The blackfeller ducked around and he passed him, looking out for him, and of course the blackfeller let drive from the side and got him. When his mate found out he got speared he just galloped away leaving the pack horses there. If he had let the blackfellers go it would not have happened, but they all had the bloody wind up. That Durack was speared three miles down at Surveyor's Hole on Farraday Creek and when they got the police and everybody together they went up to where the Waterloo road crossing is now. Before sunrise at five they raided the blackfeller's camp and the fighting was out on the flat. Those were Ngarinman blackfellers. They never ran away from the bullets, they stood and fought. Bullets went and spears went.

6 Number concepts are sometimes difficult to appreciate. Figures such as the 'thousand' cited by Jack would certainly indicate a great many souls. Grant's reference to multiples of twenty in his narrative (see note 11) probably were more realistic. Yet we cannot be sure that large-scale killings did not take place, as acknowledged by Biskup (1973:20) when he writes: 'In East Kimberley . . aboriginal reprisals were not reported until 1890. No one knew even the approximate number of the aborigines but it was believed to be large, perhaps 30,000 or more ... The number of aborigines shot by the settlers, miners .... and the police can only be guessed'. It must be remembered that the Ord River Basin was fertile, with year-round water sources and plentiful game, and that it would have been capable of supporting a relatively dense population. Elkin's (1932:297) estimate for the Kimberley as a whole was 10,000 persons and I suspect a conservative figure for the East Kimberley may have been around 6,000 to 8,000 people. While Biskup's figure does appear inflated, it is salutary. Certainly the number of Aboriginal deaths at the hands of whites was exceedingly high.

7 The spearing of John Durack or 'Big Johnnie' in November 1896 is recounted in part by Mary Durack (1959:299-301). Her report that the reprisal expedition ended inconclusively: 'The party broke up in disgust and whether further more successful reprisal measures were taken for this deed can never be known' $(1959: 286)$ stands in marked contrast to the oral tale given here. It is relevant to note Worsley's (1964:5), warning that: 'Difficult as the task may be, it is ... of ten possible to distil history out of folk legend. And it is dangerous to discount the historical value of oral tradition totally ... These sentiments are echoed by Vansina (1965:186) when he writes that 'The historian using oral traditions finds himself on exactly the same level as historians using any other kind of historical source material'. Moreover, oral traditions 'are sources which can be used for studying a fairly recent period of the past for all kinds of historical research' (1965:160). 
They did not know what the bullets looked like. They were not bad blackfellers really, they had to fight for their living, for their country. They reckon, old Boxer told me, that they fought from when the sun rose at daylight - you might as well say five o'clock - till ten o'clock when a policeman named Collins was speared. ${ }^{8}$ Collins Creek Crossing was named after him. It was not one mob of blackfellers involved but they were from everywhere - Rosewood and Spring Creek mobs - a lot round the middle of it where Kildurk station is now. A few blokes had little stations there, like Brand's Pocket. Jack Beasley and Jack Brand, all of them, had a bit of a place out in the early days. It was a wonder they never got bloody speared.

\section{Philchowski}

That was how old Philchowski was speared here too. ${ }^{9}$ It was the only time it was done here. They started fighting here once but they sort of broke it. The silly old bastard saw a mob of blackfellers at a bottle tree all heaped up so he galloped up and pulled out his squirt - bang bang bang bang - as much as to say get out of the way or something. See, when he came to that dinner camp he was half shot, returning with a pack load of grog from Wyndham to Rosewood where he worked. Anyhow, the blackfellers went away and he pulled off there, hobbled his horse out and had his dinner - I do not know whether he had dinner or grog - never thinking about those blackfellers he had fired a shot at, to twist back on him. Of course the old blackfellers had gone away all right, but just down to the creek, and they said: "That feller tryin to fuckin shoot us; we'll go an spearim". So Philchowski was just lying back having a dinner hour, reading when they came back and got him, drove the bloody spears into him. Old Wallambain was the blackfeller who killed him. They sure made a job of him then, put the spears into him and took and ate everything, the bones and tucker and left him with none. That was the only killing here. Jim Crisp, one of the stockmen at Rosewood, came down a few days later and found him. Philchowski was a cook at Rosewood. When he saw the camp he sang out, and when there was no answer he rode over and had a look: "Oh e died". Of course, he was not all smashed but he was ripe, just about stinking there when they found him. Jim Crisp rode on to Ivanhoe.

8 Mary Durack (1959:351-352) separated the spearing of John Durack and Constable Collins by about three years. According to her account, Collins was dispatched in September 1893. However, Jack Sullivan was adamant that the (orai) testimony he heard recounted the two incidents as one. That is, by his account Collins was speared no more than a week after John Durack's death, in the punitive expedition which followed: 'When that bloke got speared, this bloke come back an report an they went out an got the pack horse an everything well, they had to send for Police then an get everybody, they couldn't leave it one year halfa them. Bloke wouldn't of be laying there with a spear in is whatsaname, eh? Johnny Durack. They had to go out straight away an getim an buryim an then fought the blackfellers. That's the same year, might be only a week after. Collins was with them. When they had the fought now Collins got speared then'. (See also Gill 1977.)

9 Rudolph Philchowski, 'a Count of the German Aristocracy' (Durack 1931:5) was one of the early identities of the East Kimberley whose chief fame was that he became one of the few Europeans to be speared by Aborigines in that region. This took place near the Eight Mile Creek not far from the present township of Kununurra in July 1913. I collected several corroborative oral versions of his death at the hands of Wallambain. An example is Johnny Walker's account (collected 1973): "Well you see he had his bed... When he [Wallambain] killed him he sort of ..."Hoo". Like he sort of, well according to their word, what word we heard through them [the oldpeople who recounted the tale], he sort of, "Ohhh". He sort of sways, says "You hlack bastards". He spins around like this. He picked up the revolver: Bang bang bang bang [turning in a circle]. He only got five bullets in it. [Wallambain threw the spear at him?] He killed him first. He sort of fall down. I suppose when he tap him he pull the spear out and he nun away. He never left no spear on him, you understand. It must have gone through here, like up here somewhere see. A shovel spear y'know very big, very shovel iron'. Many persons of German nationality were roaming the north of Australia in these years, displaced from their homeland by political conflicts in Europe. 


\section{The Duracks}

I do not know whether any other Duracks shot blackfellers. These Duracks all here were never cold-blooded men like. It was before my time but I never heard that they had done any blackfellers in. Ambrose Durack would talk another bloke to do it but he never did it himself. It would be on his manager. He might say to a head stockman or somebody: 'What about do that bloke in?' That is all they did.'The head stockman or somebody else would hunt away any blackfellers hanging about the run and if they found any good young boys they would bring them home. They used to do that all round the hill, go out for a few days with some tucker and a fly for the bullocks and chase them all out. They called it 'black hunting', chasing those fellers. And if they could get a good girl when they rounded the camp and chased the mob away they might grab a couple and bring them in to the station to work, or grab a couple of young boys; the old fellers would get away. They would do that at Argyle but I never knew whether they murdered any boy. There was only one time when they grabbed a boy at the house in the night. They may have had a set on this station boy or some blooming thing. They grabbed him, kept him tied up for one day, and the next day they took him down past Hicks Creek junction somewhere and did him in, according to the old boys. They gave him tobacco and told him: "You can get away; go on, get away", but he was giving cheek and would not go. They were bailed up. "What can we do?" Charlie Darcy the white man asked the boys Boxer and old king Charlie, "We can't get away. E want to foller us back an e want to fight us". "Well", old Charlie said, "the best thing to do, putim away". See, to get him out of trouble they just put him away; I think they did that. In those days they reckoned that murdering somebody out in the bush was through the blackfeller Law, by which they sort of murdered one another, half-killing at first. You were not killed straight away. They speared you in the back I heard, knocked the boy down, gave him a few minutes, and as soon as he moved they pulled the spears out, breaking the bottle and leaving it in, and walked away. They would wipe the blood out. That was the Law. And the two little white things you see on top of the milky way at night, feathers or cloth like a white cloud, were their God or some blooming thing in their religion. They talked to those feathers, pointing a little bit of bamboo on the end of their spear if they had no gangala, fire stick. This was made from a soft tree and carried separately in a bundle with the firestick. Then they would sneak away and stop in the grass behind the bushes. The feller would gallop up: "Oh you the bloke kill me?" Another might sing out and give him an order: "Oh somebody kill you or snake bite you, or anything kill you, you finish". That was how they did it. The magic killed him in the bush according to the old blackfellers. So when he came into the station that was why they grabbed him and the white men did him in. The blackfellers did it first, murdered him first, therefore he could not get away. He had to go into the station to meet his bullet to finish him off because they gave him an order.

\section{Lissadell}

One feller at Lissadell I think shot a few. I know he split one old blackfeller with a bloody axe across the back; Jerry Durack, one of the Lissadell mob of Duracks. He was a cold-blooded feller. The blackfeller was not killed but crippled for his lifetime. He was living around Wyndham a couple of years after and would come out and frighten the other blackfellers. Old Humpy-backed Tommy they used to call him. It gave him a blooming short humpy back on. I do not know what happened over that. They told me after but I never took much notice being only a little feller. And there was the story about how two boys Charcoal and Nicholson were shot there at Dunham Gate on Lissadell. Jimmy the head boy shot Charcoal and old Daylight shot Nicholson. The two boys came down and took Jimmy's and Daylight's wives, who were nice and bloody young in those days, while they were out mustering. 


\section{ABORIGINAL HISTORY $19793: 2$}

Jimmy and Daylight had everything ready on the dray, a drum of kerosene and a stack of wood, and they burned the bodies to hide them from the police. Lake Hall was the manager at that time ${ }^{10}$ and M.J. Durack who was away came back a week later with two mules. He questioned Jimmy, who said that nothing had happened, that the two boys had run away. But M.J. said: 'You know where they are? Burnt down at Dunham Gate". However, he let them off. Those other boys had made some trouble but they should have been let off.

\section{Ningbing}

They were shooting on Ningbing all round, every settler and white man when they came into the country. I heard about those boys being shot at Ningbing. Grant told me. He was only a little snipe when his mob were shot. ${ }^{11}$ Paddy picked him up. $\mathrm{He}$ was going to be shot too but Paddy spoke to Billy Weaber or someone. Grant's sister was older than Grant and Paddy wanted her. When my uncle brought me down to Ivanhoe with old Jimmy Walker she was only a little girl somewhere around twelve years old. By then she was Billy Weiber's stud. I saw Billy Weaber in 1925 at the Six Mile. He had a big curling moustache. All those fellers went away or died. Billy Weaber went blind and died in Queensland.

That was how people were murdering one another. Instead of singing out or something those blokes would let drive. It was their own fault but it was to protect themselves. $O h$ it was a hard thing till they bloody quietened the blackfellers. It never happened to me because I was only a snipe, but by jeez I was windy all the time. I saw it and I heard it. There was an outlaw named Pigeon at Winjina Gorge down Fitzroy Crossing way but $I$ do not know a lot about him. ${ }^{12}$

\section{Major}

I heard a little about a bushranger named Major at Texas Downs when I was only a kid, but he never came over here. I was told by blokes how it started. The story was well-known then. Major was the only blackfeller who went like that in this country. He was a stock boy till a bad man named Kelly started it. Major was a fullblood, Wadaman feller. This story about him I heard from Sammy Mulga's father.

\section{Jack and I established the date as about $1917-18$.}

11 Grant Ngabidj was a fullblood Aboriginal man belonging to the Gadjerong language group, a 'tribe' located traditionally on the northern seaboard of the East Kimberley between the Cambridge Gulf (W.A.) and the Keep River (N.T.). He was born around 1904 and died in July 1977. William Weaber, the station manager, and his confreres from Queensland took up Ningbing Station in 1907-08 (Lands and Survey Department, W.A., File 3115/64, 1964, Ningbing Station, Hooker Estates Ltd). Grant witnessed these men round up many of his local group; most were shot after he and his mother and sister were removed from the scene. Thereafter he was brought up on Ningbing and Carlton Hill stations. Like many of his contemporaries he began droving and other stock work when very young. His accounts revealed an activity and vitality of Aboriginal culture unsuspected by most Europeans in the area, which was already influenced by the 'feudal' system of the cattle stations. His adult life in the $1920 \mathrm{~s}$ was violent, but became more settled in the following decade. In 1970 he moved to the camping reserve at Kununurra. I met him then but it was not until 1973 that we began to collaborate on his life history. Sadly, he died before the final completion of his book, soon to be published by the Australian Institute of Aboriginal Studies.

12 Discussing colonialism, William Willis Jr (1969:143) has remarked appropriately that: "there is heroism in the struggle against white rule'. It is likely that the number of Aboriginal reprisals against white dominance were greater than is revealed in the European histories. Aboriginal 'bushrangers' such as Pigeon in the West Kimberley (1894), Major in the East Kimberley (1908) and Nemalak in the Victoria River Downs area (1932) are part of the oral tradition among the Aborigines of those regions today. I was privileged once to witness a histrionic re-enactment of Pigeon's exploits during a secular corroboree held at Kununurra camping reserve. Pigeon's career has been described by Biskup (1973:3), Durack (1941:14-16), Idriess (1952) and Haydon (1911:318-325). 
Jack Kelly brought Major in from Darwin, reared him up, and he grew bigger and bigger. Kelly was a hard man on the boy. He used to belt Major and all that stunt, or throw him in a waterhole early in the morning. Sometimes overnight he would put him in a big sack bag and hang him up in a tree. He was a cruel feller this Kelly. ${ }^{13}$ And Major got bigger and bigger and stronger, and reckoned he got fed up with Kelly, so he got stuck into him and belted him. Every time there was any row, Major just got up and slapped old Kelly over. He was you know bluffing him, and in those days they did not like being bluffed by a blackfeller or anybody, those white fellers; they were pretty hard blokes. Anyhow, there was a policeman named Jock Miller who had resigned and was going to go away. He came to Kelly's stock camp, and Kelly spoke to the "copper. "Well", the copper said, "I can't very well do this; I'm resigned". "Yeah, but ..." he said - I think he must have paid the copper or something - "well deal to im before you go away". So they tied Major up to a tree and cut a chap, a short bit of stick, to whale him. The copper said: "Oh he might see me do it; I'll blindfold im". They blindfolded Major and as soon as that was done he handed the stick to old Kelly. See, his boss Kelly was the bloke who really dealed to him. With the stick he whaled Major, whaled him, whaled him, whaled him, and when he finished he handed the stick back to the copper and walked back and sat down. The copper came and stood, making out he was knocked up from belting him, but he was just putting it on. Then he pulled the blindfold off: "Now you know, Major, that a bit of a lesson like. It not my fault, Kelly's".

"Oh well", Kelly said, "what about takin im down with you far as the Six Mile? When you go on the boat you can sendim back". So the policeman took Major down with the chains to the Wyndham Six Mile, and when he got there he kept Major in his camp. In those days the blacks were pretty touchy then, wild like along the river here, and this copper said to Major: 'Here's a rifle Major. You're a pretty good, sensible boy. Here the gun, an here's half a packet of bullets. That protect you back to Texas. You might get killed on the road, I'll lend you the gun - you can handim back to Kelly when you get there - to save you get killed on the road". And he turned round and told Major: "You know that day that you gota hidin?" "Yes", Major said, "yes". He went on: "Not me that give you the hidin. Your boss gave you the hidin. He the bloke that deal to you". Well he should not have told Major that eh? He said: "I'm goin away now; I'm goin on the boat. You were a pretty good boy. You helped me on y'know, here an there". He knew he was a beautiful good boy, this Major, and he was not for his boss. The copper was on Major's side because he was going away. The copper stopped there and the next day he got on the boat and went away, and Major started home then back to Texas on foot. Oh he must have gone to some stations along here, Lissadell perhaps, and on to Texas. And he made up his mind: "I'll shoot the old bugger". That was his start as a bushranger. He went up there to old Growlagully station on this side of Texas, where Kelly had a station, arriving in the morning. A couple of old girls were there, sensible girls from Darwin or Queensland I think. Old Naula from Queensland was there. According to the tale, the cook blew off to the goat yard to milk the goats and Major raised the gun and shot him in the arm somewhere. I do not know whether he shot him dead. We saw it in a West Australian paper like a dictionary later on when a bloke named old Sandy picked it up over here

13 Worsley (1964:30) has remarked upon mental disorders caused by colonial warfare and colonization. The idea of a 'colonial pathology' applies both ways. Many of the colonizers appear to have been little more than thugs. Witi the exploration of the north it became common practise to 'adopt' Aboriginal children to be trained as personal servants and as stockworkers on the sheep and cattle stations. Northern New South Wales and Queensland were initial sources for child taking, since by the $1880 \mathrm{~s}$ the indigenous 'tribes' had already been decimated and individuals unattached to kinsfolk were wandering the countryside - for example, the adoptions of Nipper, Boxer and Ulysses by the Duracks (Durack 1959:330). Later the Aborigines who drifted to Darwin provided a pool of labour. 
at Gum Creek, near the pump at Cross Key when I was on Rosewood; but I knew the story before the book. I do not know who wrote it. Anyway, Kelly heard the shot and sang out to the girls: "Who that?" "That's your boy now, Major. Major comin. Go away an lock yourself, don't come out". They saw Major coming up the creek, "We'll feed you in there". "Oh", and he locked himself in the house. Major hung around there for a few days, and this old Naula told him: "Look young feller, more better you go away; don't you maka trouble. If you shoot your boss you got more worse y'see. You more better go away. You go away". That old woman had grown Major up too. She was his old grandmother who came with him from Queensland. They were on Kelly's side those old gins, all the time; that was how they saved him. Otherwise he would have been shot dead. That was Rosie, old Naula. Those Queensland girls used to carry a bloody squirt; I have seen them. They were allowed to carry them. In those days the blackfellers were wild and if any one of them lived by you or me we would be allowed to carry a gun, part-castes and any old girl too who was sensible. In those days the old girls were hard on the blacks too. They would string them up, flog a man, young boys with a whip to make them work for the boss. Half castes had a better life than the fullbloods.

So Major went away, hanging around in the bush, and he came down to Blackfeller's Creek between Lissadell and Turkey Creek. Old Blackfeller Creek station crosses the main road to Hall's Creek about eight or nine miles down from Turkey Creek. It was the outstation to Lissadell according to the old fellers. Major picked up a few boys and sneaked down onto two blokes there early in the morning and killed them. He whaled one bloke with a wheel spoke - old George Fettel the caretaker and when the cook jumped out he hit him across the head with a hammer or something. He picked up more ammunition, guns and tucker from there and with a couple of boys they took all the girls from there into the bush. They went to Violet Valley and stayed for more than a year. The others had to go with him because he had the gun.

Major hung about in a cave on a big hill in Growlagully country where they could not get to him. He made a ladder or something which he could pull up so that nobody could climb up, and put all his girls up there. By gee he was a tricky bloke! He would sneak away and shoot a kangaroo or a bullock and bring them back and have a feed up there with all his wives and a couple of old blackfellers. From the top he could watch out all the time and people could not come round on him from the other side. This was from out at Spring Creek, now Texas Downs country, hanging around the Djaru people. Major was brought up Djaru and half-Gidja, half and half. The Djaru people were at the top end of the Nine Mile way at Mistake Creek and around Turkey Creek and Texas they all talked Gidja.

After one or two years Major left that blooming big hill. He spoke the Wadaman language and, silly bugger, he wanted to go back to Darwin, through Wave Hill. If he had stayed on that big hill he would still be there. He had his cousin-brother at Rosewood here, and they reckon he came in there one night and told big Darwin Neville: "I'm goin back now cousin. Give me a hand shake". And he gave him a hand shake. "That's the last I see you. I think I'll be shot". I do not know what brought it to his mind when he said that. "In a few days", he said, "I'll be leavin Growlagully goin across to my country. I'll be shot between my country an there. They'll catch me there now. Y'see I gotta go away. I'm fed up now. I don't give a damn hand about be shot or not. I done me day, I shot a few whites" - those two he killed at Blackfeller Creek and the one at Growlagully.

He went back towards the Nine Mile that night after seeing his cousin. That was the time he must have started to come across. Walking all the time, never riding a horse, Major went across up the river to Red Butte, and that was where they found his tracks. The bloody Wyndham, Hall's Creek, Turkey Creek and Wave Hill police were out looking for him, all the police boys and stockmen, the managers I suppose, a big 
mob on his trail. He went across from Red Butte over the river on to the Spring Creek side, but not to Spring Creek - further up across to the Nine Mile - and out into the open then. He should have kept to the hills where he would have been safe. The Nine Mile is on the road going up to Ord River from Spring Creek. It is a highway now. When he shifted across and camped half-way they were on his wheel then. Next morning at sunrise on a little Nine Mile jump-up they got him. They fought and fought for a bloody good while. They shot a couple of boys down and some others ran away. And Major shot a bloody policeman through the ears. They got the other two boys first, shot down, but never old Major. He was behind an antbed with bullets hitting here and there. One of the old girls was loading the gun for him. He had a forty-four rifle then and I think a pistol too, six-shooters those old guns. They fought till they got him. They ended up shooting the oId gin, who was loading the gun, through the bub. That buggered her, and one feller sneaked around and got him, shooting him in the arm. When that happened he could no longer load his gun. He lifted up his hands: "You got me", and they walked up and did him in. They shot him little by little - it was not a clean death - and cut off his hand and took it back. They could have taken him back alive, poor bugger. ${ }^{14}$

Major had two boys with him, and himself and five or six wives. One of those old girls only died two or three years back - Nancy the last one who died from Bow River; that was a long time she was living and she was not grey-haired at all. Her son Jimmy is around somewhere. I do not remember the year Major was shot because I was only a snipe. You might as well say 1905 or 1906 . That is all I know about Major, what I heard from the old people. In the end he could not get his own master. He wanted to get old Jack Kelly his boss but there was no chance. Kelly always had his partners, like that old old gin. Only for that old girl who reared up Major, saved $h$ is life.

14 It is instructive to compare this oral version with three documentary sources: Fanning's original report contained in a West Australian Police Letterbook (1908-1910), a newspaper article written by Mary Durack (1932:7), and a brief mention in Buchanan (1934:168-171). If we attempted to establish beyond a doubt the reliability of one version over another, we would confront the difficulties of individual reporting and interpretation that are illustrated so well in the classic film 'Rashomon'. The rifle duel in which Major died took place in September 1908. The oral history related by Jack mentions irregularities in Major's death, but these were not revealed in the report of Constable Fanning (who headed the search party), nor by Durack or Buchanan. In these written testimonies descriptions of the final shoot-out are abbreviated. Vansina insists that social and cultural context affects the content of oral (and written) tales, and that 'Traditions are altered, more or less consciously, to fit in with the cultural values of the time' (1965:96). For example, the tone of Fanning's report is self-congratulatory: 'The jury added a rider to the effect we consider great credit is due to Constable Fanning for the most able manner in which he carried out his Duty under great and dangerous difficulties' (West Australian Police Letterbook 1908-10: 32). According to this source, there was a running battle. Major was wounded in the right wrist but could still use his rifle. Interestingly, Fanning declared that the woman Naula ('Knowla') was present (it was she who was wounded in the right side of the breast) and two other Aboriginal men (Dibbie and Nipper) were killed during this punitive expedition. Durack's version stressed two themes which are to be found in many of her other writings, feminine intrigue and 'savagery' versus 'civilisation': thus it was a jilted girl-friend named Biddy who purportedly betrayed Major, and the outlaw himself is painted as having the mind of a civilised man at war with the heart of a savage .. In Durack's version Major did not surrender and Naula died soon afterwards. Similarities in the description of the shooting, and the mis-spelling of 'Knowla', suggest that Durack may have used the police report as her main source. Jack Sullivan's oral version shifts the moral emphasis, extolling Major's courage and providing justification for his hatred of Europeans, Jack Kelly in particular. But all three narratives contain a common core of agreement on 'facts' and they are paradoxically complementary in the negative evidence they contain. 
White men did not understand the blackfellers much. I have an old book about how the white man came out in the early days, how they formed Brisbane, and Melbourne in Victoria. There were only humpies and nothing else. You could see the river where they were, and they came out on a little launch to get themselves a place. And the next time you looked, opening at another page, you could see the bridge over that same place. I can bloody nearly reaci it. I heard the story before about when they first saw the white men over here now when they started coming out. You could see it in that old book where the blackfellers met the white men and everything. They got a little bit tame and although they wanted to kill this and kill that one, I think the leader blackfellers must have studied that they were the same humans as you and me even though I am a different colour - and they left the hand up of their own tribe: "Now don't kill this man". They must have said that: "They same as you and me". You can see how they started off all in that book, getting old tomahawks and scissors, old knives, a bag of flour, tobacco, tea and sugar. It is worthwhile to read that.

\section{DARWIN COMMUNITY COLLEGE}

and

TURKEY CREEK, W.A.

\section{BIBLIOGRAPHY}

Barwick, Diane, James Urry and David Bennett. 'A select bibliography of Aboriginal history and social change: theses and published research to $1976^{\prime}$, A boriginal History, 1 (2), 1977:111-169.

Batty, Joyce D. Namatjira: wanderer between two worlds. Melbourne, 1963.

Biskup, Peter. Not slaves not citizens. St Lucia, 1973.

Buchanan, Gordon. Packhorse and waterhole. Sydney, 1934.

Durack, Mary. 'Rudolph Philchowski', West Australian, 16 May $1931: 5$.

'Major the outlaw', West Australian, 14 May 1932:7.

All-about: the story of a black community on Argyle station, Kimberley. Sydney, 1935.

Chunume. Sydney, 1936.

Son of Djaro. Sy dney, 1940.

'The outlaws of Windginna Gorge', Walkabout, 1 June 1941:14-16.

Kings in grass castles. London, 1959.

Durack, P.M. 'Pioneering the East Kimberleys', Historical Society of Western Australia, Journal, 2 (14), 1933:1-46.

Elkin, A.P. 'Social organization in the Kimberley Division', Oceania, 2 (3), 1932:296-333.

Gill, Andrew. 'Aborigines, settlers and police in the Kimberley, 1887-1905', Studies in Westerr Australian History, (1), $1977: 1-28$.

Haydon, A.L. The trooper police of Australia. London, 1911.

Hilliard, Winifred. The people in between London, 1968.

Idriess, Tom. Outlaws of the Leopolds. Sydney, 1952.

McGrath, Ann. 'Tamed blacks'? Frontier paternalism and control, (unpublished postgraduate seminar paper), History Department, LaTrobe University, October 1978.

Meggitt, M.J. Desert People. Sydney, 1962.

Palmer, Kingsley and Clancy McKenna. Somewhere between black and white. Sydney, 1978.

Vansina, Jan. Oral tradition: a study in historical methodology. Harmondsworth, 1965.

West Australian Police. Letterbook, 21 July 1908 - 14 May 19 10:36-37; 153-154.

Willis, William Jr. 'Skeletons in the anthropological closet', in Hymes, Dell ed. Reinventing anthropology. New York, 1966:121-152.

Worsley, Peter. The third world. London, 1964. 